\title{
EDN1 Gene
}

National Cancer Institute

\section{Source}

National Cancer Institute. EDN1 Gene. NCI Thesaurus. Code C28577.

This gene plays a role in active $\mathrm{Na}-\mathrm{K}$ transport, vasoconstriction and pain mediation. 